\title{
HUBUNGAN ANTARA SELF CONFIDENCE DENGAN KEMAMPUAN PEMECAHAN MASALAH MATEMATIS SISWA SMA
}

\author{
Annisa Wulandari ${ }^{1}$, Ali Nurcahya ${ }^{2}$, Gida Kadarisma ${ }^{3}$ \\ 1,2,3 IKIP Siliwangi, Jl. Terusan Jenderal Sudirman, Cimahi, Jawa Barat, Indonesia \\ ${ }^{1}$ awascawankonstan@gmail.com, ${ }^{2}$ lay.nurcahya30@gmail.com, ${ }^{3}$ gidakadarisma@ikipsiliwangi.ac.id
}

\begin{abstract}
This study aims to know in depth about the relationship of self-confidence simultaneously to the ability of solving mathematical problems of high school students. The population in this research is one of the high schools in Cililin. The instrument in this research is a test of mathematical problem solving ability of five items, and self confidence questionnaire of students. Methods in this research use correlational research. The results of this research show that there is a relationship between self confidence on the problem solving ability of high school students is correlation value (r) on Pearson Corellation between self confidence with students mathematical problem solving ability is equal to 0,824. From these results indicate the level of relationships that are strong and indicate the direction of a positive relationship.
\end{abstract}

Keywords: Problem Solving Ability, Self Confidence

\begin{abstract}
Abstrak
Penelitian ini bertujuan untuk mengetahui secara mendalam mengenai hubungan self confidence secara simultan terhadap kemampuan pemecahan masalah matematis siswa SMA. Populasi dalam riset ini ialah salah satu SMA di Cililin. Instrumen dalam riset ini berupa tes kemampuan pemecahan masalah matematis sejumlah lima butir soal, dan angket self confidence siswa. Metode dalam riset ini memakai penelitian korelasional. Hasil riset ini menunjukan bahwa ada hubungan antara self confidence terhadap kemampuan pemecahan masalah siswa SMA yaitu nilai korelasi (r) pada Pearson Corellation antara self confidence dengan kemampuan pemecahan masalah matematis siswa ialah sebesar $0,824 * *$. Dari hasil tersebut menunjukkan tingkat hubungan yang tergolong kuat dan menunjukan arah hubungan yang positif.
\end{abstract}

Kata Kunci: Kemampuan Pemecahan Masalah, Self Confidence

How to cite : Wulandari, A., Nurcahya, A., Kadarisma, G. (2018). Hubungan antara Self Confidence dengan Kemampuan Pemecahan Masalah Matematis Siswa SMA. JPMI - Jurnal Pembelajaran Matematika Inovatif, 1 (4), 799-806.

\section{PENDAHULUAN}

Pendidikan merupakan suatu proses pengembangan kepribadian manusia yang meliputi nilai, pengetahuan, sikap, dan keterampilan. Pendidikan di Indonesia bertujuan untuk mencerdaskan kehidupan dan menghilangkan kebodohan bangsa Indonesia (Fitriani, 2015). Maka, mutu pendidikan harus selalu berkembang dengan mengikuti perkembangan zaman, salah satunya melalui pendidikan matematika yang diajarkan kepada siswa di tingkat pendidikan.

Matematika ialah salah satu pelajaran yang berguna untuk memaksimalkan kemampuan menghitung, mengukur, juga menerapkan rumus matematika dalam kehidupan sehari-hari. Matematika adalah ilmu yang sangat bermanfaat dalam menyelesaikan permasalahan dalam 
kehidupan sehari-hari juga dalam upaya memahami ilmu pengetahuan lainnya (Kadarisma, 2014).

Matematika menjadi ilmu yang tidak bisa terpisah dengan kehidupan sehari-hari. Pada dasarnya pembelajaran matematika di tingkat sekolah merupakan awal dari terbentuknya masyarakat maju (Sariningsih \& Kadarisma, 2016). Dengan menguasai ilmu matematika, maka permasalahan yang ditemui dalam kehidupan sehari-hari akan mudah untuk diselesaikan.

Matematika memiliki peranan penting sebagai pembentuk pola pikir yang cerdas juga menjadi hal yang sangat diperlukan bagi kehidupan masyarakat modern, karena dapat membuat masyarakat menjadi lebih percaya diri, terbuka juga mudah menyesuaikan dengan bermacammacam situasi dan permasalahan. Menurut Fathani (Hendriana, 2014) salah satu ciri pembelajaran matematika yang manusiawi adalah bukan hanya memperlihatkan konsep atau rumus matematika saja, tetapi juga menunjukkan mengenai aplikasi beserta manfaatnya dalam kehidupan sehari-hari, dimana ketika menginformasikannya disesuaikan dengan tingkatan atau jenjang sekolah siswa. Sedangkan kenyataannya pada pembelajaran matematika di sekolah, siswa biasanya dihadapkan dengan hapalan rumus dan latihan soal yang bersifat rutin. Hal tersebut membuat kemampuan matematis siswa menjadi tidak terlatih dan menyebabkan prestasi siswa di pelajaran matematika menjadi rendah.

Rendahnya prestasi siswa di Indonesia dapat terlihat dari hasil studi PISA tahun 2015 yang dilakukan pada siswa berusia 15 tahun, dimana Indonesia menempati peringkat ke-62 dari 70 negara peserta untuk kategori matematika (OECD, 2016). Selain itu, hasil studi TIMSS tahun 2015 yang dilakukan untuk mengukur pencapaian matematika dan IPA siswa di tingkat SD/MI pada studi internasional dengan target populasi di Indonesia yaitu siswa kelas 4, juga menempatkan Indonesia pada posisi ke-45 dari 50 negara peserta untuk kategori matematika (Pusat Penilaian Pendidikan Badan Penelitian dan Pengembangan, 2016). Dari kedua hasil studi tersebut dapat disimpulkan bahwa prestasi siswa Indonesia pada kategori matematika di tingkat internasional masih rendah bila dibandingkan dengan negara lainnya.

Faktor yang kemungkinan menjadi penyebab rendahnya prestasi siswa di Indonesia adalah belum terpenuhinya standar-standar matematis. NCTM (Effendi, 2012) menyebutkan bahwa standar kemampuan matematis yang harus dimiliki dan dikuasai oleh siswa yaitu kemampuan problem solving (pemecahan masalah), communication (komunikasi), connection (koneksi), reasoning (penalaran), dan representation (representasi). Kelima faktor tersebut harus dimiliki oleh masing-masing peserta didik agar mutu pendidikan dapat meningkat sesuai dengan yang diharapkan. Sedangkan menurut Sumarmo (Nurqolbiah, 2016), kemampuan dasar matematika yang wajib dimiliki siswa diklasifikasikan dalam lima jenis yaitu: (1) kemampuan mengenal, memahami sekaligus menerapkan konsep, prosedur, prinsip juga ide matematika, (2) menyelesaikan masalah matematik, (3) bernalar matematik, (4) melakukan koneksi matematik. Dari uraian tersebut dapat disimpulkan bahwa kemampuan pemecahan masalah matematis merupakan kemampuan yang paling krusial dan harus dimiliki oleh peserta didik.

Branca (Sumartini, 2016) menyatakan kemampuan pemecahan masalah matematis sangat penting dimiliki oleh setiap siswa karena: (1) pemecahan masalah adalah tujuan dari pengajaran matematika secara umum, (2) pemecahan masalah yang berhubungan dengan metoda, prosedur dan strategi adalah proses pokok dan utama di dalam kurikulum matematika, dan (3) pemecahan masalah adalah kemampuan awal dalam belajar matematika. 
NTCM (Rosdianwinata, 2015) menyebutkan bahwa memecahkan masalah bukan saja merupakan suatu sasaran belajar matematika, tetapi sekaligus merupakan alat utama untuk melakukan belajar itu. Oleh karenanya, kemampuan pemecahan masalah ini menjadi fokus pembelajaran matematika disemua jejang pendidikan, dari sekolah dasar hingga perguruan tinggi. Dengan mempelajari pemecahan masalah dalam matematika, siswa akan terlatih dan mengetahui cara-cara berfikir, tekun dalam suatu persoalan dan memiliki rasa keingintahuan yang tinggi mengenai suatu permasalahan, serta akan melatih rasa percaya diri siswa dalam berbagai macam situasi yang tidak biasa mereka hadapi, baik situasi sebelum, sedang, ataupun yang akan dihadapi dalam kehidupan bermasyarakat.

Ada beberapa aspek dalam kemampuan pemecahan masalah agar prestasi belajar siswa meningkat. Menurut Polya (Hadi \& Radiyatul, 2014) terdapat empat aspek dalam kemampuan pemecahan masalah, diantaranya sebagai berikut:

1. Memahami masalah

Dalam memahami masalah meliputi identifikasi, membuat rangkuman dari fakta-fakta, bahkan masalah yang ringkaspun ditelaah secara berulang-ulang agar dapat dipahami dengan seksama.

2. Menentukan rencana strategi pemecahan masalah

Dalam tahap ini masing-masing solusi pemecahan masalah dirinci secara detail disesuaikan dengan masalah-masalah yang disediakan. Selain itu, siswa diharuskan memiliki pengalaman-pengalaman dalam menyelesaikan masalah untuk kemudian diterapkan dalam strategi penyelesaian masalah.

3. Menyelesaikan strategi penyelesaian masalah

Agar solusi yang dicari sesuai dengan jawaban yang diinginkan, maka strategi pemecahan hasus dilaksanakan secara hati-hati. Berbagai macam soal dalam bentuk tabel, diagram ataupun simbol harus dirinci seruntut mungkin agar si pemecah masalah tidak merasa kebingungan ketika dituntut untuk menyelesaikan masalah tersebut.

4. Memeriksa kembali jawaban yang diperoleh

Dalam aspek ini berbagai solusi harus dipertimbangkan dan cocok dengan inti permasalahan.

Adapun aspek yang digunakan dalam penelitian ini sebagai indikator kemampuan pemecahan masalah matematis adalah: (1) memahami masalah, (2) menentukan rencana strategi pemecahan masalah, dan (3) menyelesaikan strategi penyelesaian masalah (Hidayat, \& Sariningsih, 2018; Wahyu, 2014).

Selain kemampuan kognitif seperti kemampuan pemecahan masalah matematis, siswa juga perlu memiliki kemampuan afektif yang baik, salah satunya adalah kepercayaan diri (self confidence). Rasa percaya diri siswa berkaitan juga dengan kemampuan terhadap pemecahan masalah matematis siswa tersebut. Karena untuk menyelesaikan masalah matematis salah satunya diperlukan rasa percaya diri. Siswa yang percaya terhadap kemampuannya akan lebih mudah dalam menyusun strategi dalam menyelesaikan masalah matematis. Sedangkan siswa yang kurang percaya diri akan merasa bahwa dirinya tidak mampu dalam menyelesaikan masalah matematis secara baik walaupun hanya berupa masalah matematis yang sederhana (Sumarmo, Mulyani, \& Hidayat, 2018; Tresnawati, Hidayat, \& Rohaeti, 2017).

Rakhmat (Hendriana, 2012) mengungkapkan bahwa percaya diri atau keyakinan diri merupakan kepercayaan kepada diri sendiri yang dimiliki oleh seseorang di dalam kehidupannya. Menurut Lauster (Suryanti, 2015) terdapat beberapa karakteristik untuk 
menilai kepercayaan diri individu, diantaranya: (1) percaya dengan kemampuan sendiri, (2) bertindak secara mandiri dalam pengambilan keputusan, (3) mempunyai konsep diri yang positif, (4) berani mengungkapkan pendapat. Sedangkan Margono (Martyanti, 2013) mengungkapkan tiga aspek kepercayaan diri siswa ketika mempelajari matematika, yaitu: (1) kepercayaan terhadap pemahaman juga kesadaran diri terhadap kemampuan matematikanya, (2) kemampuan dalam menentukan secara realistik target yang ingin diraih dan menyusun strategi sebagai usaha meraih target tersebut, serta (3) percaya dengan matematika itu sendiri.

Dari beberapa pendapat yang diungkapkan para ahli tersebut, maka dalam penelitian ini diambil beberapa aspek yang digunakan sebagai indikator kepercayaan diri siswa, yaitu: (1) kepercayaan terhadap pemahaman juga kesadaran diri terhadap kemampuan matematikanya, (2) bertindak secara mandiri dalam pengambilan keputusan, (3) mempunyai konsep diri yang positif, (4) kemampuan dalam menentukan secara realistik target yang ingin diraih dan menyusun strategi sebagai usaha meraih target tersebut, dan (5) percaya dengan matematika itu sendiri.

Berdasarkan ulasan di atas, maka peneliti mencoba melakukan penelitian yang bertujuan untuk mengetahui dan menelaah hubungan antara kepercayaan diri terhadap kemampuan pemecahan masalah matematis siswa SMA dan seberapa kuat hubungan antara kepercayaan diri terhadap kemampuan pemecahan masalah matematis siswa SMA ditinjau dari masingmasing indicator, baik kemampuan pemecahan masalah maupun self confidence itu sendiri.

\section{METODE}

Dalam penelitian ini digunakan metode penelitian korelasional, dimana populasinya yaitu seluruh kelas XI siswa SMA Muslimin Cililin, kemudian dipilih satu kelas dengan teknik random sampling untuk dijadikan sampel. Adapun instrumen dalam penelitian ini yaitu instrumen berupa tes uraian mengenai kemampuan pemecahan masalah matematis yang terdiri sebanyak 6 butir soal dan angket self confidence yang terdiri dari 15 butir pernyataan positif (+) dan 15 butir pernyataan negatif (-). Hasil data yang didapat kemudian dianalisis untuk menentukan seberapa kuat korelasinya dengan melihat koefisien korelasi, dimana data tersebut diolah menggunakan Product Moment Pearson untuk data yang berdistribusi normal atau menggunakan Spearman untuk data yang tidak berdistribusi normal.

\section{HASIL DAN PEMBAHASAN}

Hipotesis dalam penelitian ini adalah "Adanya hubungan yang positif antara kepercayaan diri dan kemampuan pemecahan masalah matematis siswa". Untuk menguji hipotesis tersebut, maka dilakukan pengolahan data untuk melihat seberapa kuat korelasinya. Namun, sebelum menguji korelasi terlebih dahulu dilakukan uji normalitas sebagai prasyarat dengan nilai signifikansi sebesar 0,05 . Uji normalitas ini digunakan untuk menguji apakah data yang dimiliki berdistribusi normal atau tidak, dimana hipotesis yang akan diuji adalah:

$\mathrm{H}_{0}$ : Data self confidence dan kemampuan pemecahan masalah matematis siswa berdistribusi normal

$\mathrm{H}_{1}$ : Data self confidence dan kemampuan pemecahan masalah matematis siswa tidak berdistribusi normal

Kriteria pengambilan keputusan pada uji normalitas adalah sebagai berikut:

Jika nilai signifikansi lebih kecil dari 0,05 maka $\mathrm{H}_{0}$ ditolak

Jika nilai signifikansi lebih besar sama dengan 0,05 maka $\mathrm{H}_{0}$ diterima 
Berikut ini merupakan hasil dari analisis uji normalitas:

Tabel 1. Uji Normalitas Data Self Confidence dengan Kemampuan Pemecahan Masalah

\begin{tabular}{|c|c|c|c|}
\hline & & $\begin{array}{l}\text { Angket Self } \\
\text { Confidence }\end{array}$ & $\begin{array}{c}\text { Tes Kemampuan } \\
\text { Pemecahan Masalah } \\
\text { Matematis }\end{array}$ \\
\hline \multicolumn{2}{|l|}{$\mathrm{N}$} & 35 & 35 \\
\hline \multirow[b]{2}{*}{ Normal Parameters ${ }^{\mathrm{a}, \mathrm{b}}$} & Mean & 94.91 & 9.31 \\
\hline & Std. Deviation & 16.983 & 1.586 \\
\hline \multirow{3}{*}{$\begin{array}{l}\text { Most Extreme } \\
\text { Differences }\end{array}$} & Absolute & 0.172 & 0.179 \\
\hline & Positive & 0.172 & 0.179 \\
\hline & Negative & -.114 & -.107 \\
\hline \multicolumn{2}{|c|}{ Kolmogorov-Smirnov Z } & 1.019 & 1.056 \\
\hline \multicolumn{2}{|l|}{ Asymp. Sig. (2-tailed) } & 0.250 & 0.215 \\
\hline
\end{tabular}

a. Test distribution is Normal.

b. Calculated from data.

Dari hasil uji normalitas pada Tabel 1, terlihat bahwa nilai signifikansi yang didapat pada hasil angket self confidence yaitu sebesar 0,250 dan pada hasil tes kemampuan pemecahan masalah matematis siswa yaitu sebesar 0,215 . Keduanya menunjukkan nilai signifikansi yang lebih besar dari 0,05 ( $\mathrm{H}_{0}$ diterima). Artinya baik data self confidence maupun kemampuan pemecahan masalah matematis siswa keduanya berdistribusi normal.

Selanjutnya, dilakukan pengolahan data untuk menganalisis seberapa kuat korelasi antara self confidence dengan kemampuan pemecahan masalah matematis siswa. Karena hasil uji normalitas menunjukkan bahwa kedua data berdistribusi normal, maka selanjutnya dipilih Product Moment Pearson dengan taraf signifikansi 0,05 untuk menentukan seberapa kuat korelasi antara kepercayaan diri dengan kemampuan pemecahan masalah matematis siswa. Berikut adalah hipotesis yang diuji:

$\mathrm{H}_{0}$ : tidak terdapat hubungan yang signifikan antara kepercayaan diri dengan kemampuan pemecahan masalah matematis siswa

$\mathrm{H}_{1}$ : terdapat hubungan yang signifikan antara kepercayaan diri dengan kemampuan pemecahan masalah matematis siswa

Kriteria pengujian yang digunakan adalah:

Jika signifikansi nilainya lebih besar sama dengan 0,05 maka $\mathrm{H}_{0}$ diterima

Jika signifikansi nilaiya lebih kecil dari 0,05 maka $\mathrm{H}_{0}$ ditolak

Adapun pedoman interpretasi koefisien korelasi menurut Sugiyono (2013) adalah sebagai berikut:

Tabel 2. Pedoman Interpretasi Koefisien Korelasi

\begin{tabular}{cc}
\hline Interval Koefisien & Tingkat Hubungan \\
\hline $0,00-0,199$ & Sangat Lemah \\
$0,20-0,399$ & Lemah \\
$0,40-0,599$ & Sedang \\
$0,60-0,799$ & Kuat \\
$0,80-1,000$ & Sangat Kuat \\
\hline
\end{tabular}


Terdapat dua cara yang dapat dilakukan dalam pengambilan keputusan pada analisis korelasi, yaitu dilihat dari nilai signifikansi (sig. 2-tailed) dan tanda bintang (*) pada nilai korelasi yang ditunjukkan oleh Pearson Corellation yang dihasilkan dari perhitungan SPSS. Antara variabel yang dianalisis memiliki korelasi yang kuat apabila nilai signifikansi yang diperoleh lebih kecil dari 0,05 atau terdapat tanda bintang (*) pada nilai korelasi yang ditunjukkan oleh Pearson Corellation. Berikut ini merupakan hasil pengolahan korelasi dengan menggunakan Product Moment Pearson:

Tabel 3. Uji Korelasi antara Self Confidence dengan Kemampuan Pemecahan Masalah

\begin{tabular}{|c|c|c|c|}
\hline & & $\begin{array}{l}\text { Angket Self } \\
\text { Confidence }\end{array}$ & $\begin{array}{c}\text { Tes Kemampuan } \\
\text { Pemecahan Masalah } \\
\text { Matematis }\end{array}$ \\
\hline & Pearson & 1 & $0.824^{* *}$ \\
\hline Angket Self & Correlation & & \\
\hline Confidence & Sig. (2-tailed) & & 0.000 \\
\hline & $\mathrm{N}$ & 35 & 35 \\
\hline Tes Kemampuan & Pearson & $0.824^{* *}$ & 1 \\
\hline Pemecahan & $\begin{array}{l}\text { Correlation } \\
\text { Sig. (2-tailed) }\end{array}$ & 0.000 & \\
\hline Masalah Matematis & $\mathrm{N}$ & 35 & 35 \\
\hline
\end{tabular}

**. Correlation is significant at the 0.01 level (2-tailed).

Dari hasil uji korelasi Product Moment Pearson pada Tabel 3, terlihat bahwa nilai korelasi (r) pada Pearson Corellation antara kepercayaan diri dengan kemampuan pemecahan masalah matematis siswa adalah sebesar $0,824^{* *}$ dan nilai signifikansi yang dihasilkan adalah sebesar $0,000<0,05$. Dari hasil tersebut dapat disimpulkan bahwa terdapat korelasi antara kepercayaan diri dengan kemampuan pemecahan masalah matematis siswa. Hasil tersebut menunjukkan interpretasi yang sangat kuat antara self confidence dengan kemampuan pemecahan masalah matematis siswa.

\section{Pembahasan}

Hasil ini sejalan dengan penelitian yang dilakukan oleh Wulandari \& Sinambela (2017) di kelas X MAN Kisaran, dimana hasilnya menunjukkan korelasi antara kepercayaan diri siswa dengan kemampuan pemecahan masalah matematika sebesar 0,94 yang artinya kepercayaan diri dan kemampuan pemecahan masalah matematis siswa terdapat korelasi yang sangat kuat. Selain itu hasil penelitian ini juga diperkuat dengan pendapat Romberg (Widjajanti, 2009) yang menyebutkan bahwa terdapat 5 tujuan belajar matematika bagi siswa, yaitu: (1) belajar mengenai nilai matematika, (2) siswa menjadi lebih percaya pada kemampuannya sendiri, (3) siswa dapat memecahkan masalah matematika, (4) siswa dapat belajar berkomunikasi secara matematis, dan (5) siswa dapat belajar bernalar secara matematis. Dari teori tersebut dapat disimpulkan bahwa self confidence maupun kemampuan pemecahan masalah matematis siswa merupakan dua hal yang saling berhubungan.

\section{KESIMPULAN}

Berdasarkan hasil penelitian dan pembahasan, dapat diambil kesimpulan sebagai berikut:

1. Antara kepercayaan diri dan kemampuan pemecahan masalah matematis siswa terdapat korelasi yang sangat kuat $(r=0,824$ dan nilai signifikansi $=0,000<0,05)$.

2. Kuatnya korelasi antara kepercayaan diri dan kemampuan pemecahan masalah matematis siswa menunjukkan bahwa semakin tinggi kepercayaan diri siswa maka akan semakin 
tinggi pula kemampuan pemecahan masalah matematis siswa tersebut, begitu juga sebaliknya.

\section{DAFTAR PUSTAKA}

Effendi, L. A. (2012). Pembelajaran Matematika dengan Metode Penemuan Terbimbing untuk Meningkatkan Kemampuan Representasi dan Pemecahan Masalah Matematis Siswa SMP. Jurnal Penelitian Pendidikan, 13(2), 1-10.

Fitriani, N. (2015). Hubungan antara Kemampuan Pemecahan Masalah Matematis dengan Self Confidence Siswa SMP yang menggunakan Pendekatan Pendidikan Matematika Realistik. Jurnal Euclid, 2(2), 341-351.

Hadi, S., \& Radiyatul. (2014). Metode Pemecahan Masalah Menurut Polya untuk Mengembangkan Kemampuan Siswa dalam Pemecahan Masalah Matematis di Sekolah Menengah Pertama. Edu-Mat Jurnal Pendidikan Matematika, 2(1), 53-61. Retrieved from http://ppjp.unlam.ac.id/journal/index.php/edumat/article/view/603

Hendriana, H. (2012). Pembelajaran Matematika Humanis dengan Metaphorical Thinking untuk Meningkatkan Kepercayaan Diri Siswa. Jurnal Infinity, 1(1), 90-103. https://doi.org/10.22460/infinity.v1i1.9

Hendriana, H. (2014). Membangun Kepercayaan Diri Siswa melalui Pembelajaran Matematika Humanis. Jurnal Pengajaran MIPA, 19(1), 52-60.

Hidayat, W., \& Sariningsih, R. (2018). Kemampuan Pemecahan Masalah Matematis dan Adversity Quotient Siswa SMP Melalui Pembelajaran Open Ended. JNPM (Jurnal Nasional Pendidikan Matematika), 2(1), 109-118.

Kadarisma, G. (2014). Meningkatkan Kemampuan Pemahaman Matematik Siswa SMP melalui Model Pembelajaran Generatif. In M. L. E. J. Riajanto, I. Permana, \& D. Firmansyah (Eds.), Prosiding Seminar Nasional Pendidikan Matematika "Implementasi Kurikulum 2013 melalui Inovasi Pembelajaran Matematika untuk Menunjang Optimalnya Hardskill dan Softskill Siswa” (pp. 217-223). Cimahi: STKIP Siliwangi.

Martyanti, A. (2013). Membangun Self-Cofidence Siswa dalam Pembelajaran Matematika dengan Pendekatan Problem Solving. In Prosiding Seminar Nasional Matematika dan Pendidikan Matematika FMIPA UNY (pp. 15-22). Yogyakarta: Universitas Negeri Yogyakarta.

Nurqolbiah, S. (2016). Peningkatan Kemampuan Pemecahan Masalah, Berpikir Kreatif dan Self-Confidence Siswa melalui Model Pembelajaran Berbasis Masalah. JP3M (Jurnal Penelitian Pendidikan Dan Pengajaran Matematika), 2(2), 143-158. Retrieved from jurnal.unsil.ac.id/index.php/jp3m

OECD. (2016). PISA 2015 Results in Focus. OECD. https://doi.org/10.1787/9789264266490en

Pusat Penilaian Pendidikan Badan Penelitian dan Pengembangan. (2016). Trends in International Mathematics and Science Study, Result From TIMSS 2015. Pusat Penilaian Pendidikan Badan Penelitian dan Pengembangan. 
Rosdianwinata, E. (2015). Penerapan Metode Discovery untuk Meningkatkan Kemampuan Pemecahan Masalah Matematika Siswa. MENDIDIK: Jurnal Kajian Pendidikan Dan Pengajaran Penerapan Metode Discovery U, 1(1), 1-8.

Sariningsih, R., \& Kadarisma, G. (2016). Meningkatkan Kemampuan Berpikir Kreatif Matematis dan Kemandirian Belajar Siswa SMP melalui Pendekatan Saintifik Berbasis Etnomatematika. Jurnal Ilmiah UPT P2M STKIP Siliwangi, 3(1), 53-56.

Sugiyono. (2013). Metode Penelitian Pendidikan (Pendekatan Kuantitatif, Kualitatif, dan $R \& D)$. Bandung: Alfabeta.

Sumarmo, U., Mulyani, E., \& Hidayat, W. (2018). Mathematical Communication Ability and Self Confidence Experiment with Eleventh Grade Students Using Scientific Approach. JIML-Journal of Innovative Mathematics Learning, 1(1), 19-30.

Sumartini, T. S. (2016). Peningkatan Kemampuan Pemecahan Masalah Matematis Siswa melalui Pembelajaran Berbasis Masalah. Mosharafa: Jurnal Pendidikan Matematika, 5(2), 148-158. Retrieved from http:/emosharafa.org/index.php/mosharafa/article/view/mv5n2_12/179

Suryanti, S. (2015). Peningkatan Kepercayaan Diri dan Kemampuan Pemecahan Masalah Mahasiswa pada Mata Kuliah Matematika Diskrit melalui Discovery Learning. Jurnal Didaktika, 22(1), 64-73.

Tresnawati, T., Hidayat, W., \& Rohaeti, E. E. (2017). Kemampuan Berpikir Kritis Matematis dan Kepercayaan Diri Siswa SMA. Symmetry: Pasundan Journal of Research in Mathematics Learning and Education, 2(2), 39-45.

Wahyu, H. (2014). The Implementation of MEAs Instruction to Students' Mathematics Problem Solving and Connecting Ability. In Proceeding of International Conference on Research, Implementation and Education of Mathematics and Sciences 2014. Yogyakarta State University.

Widjajanti, D. B. (2009). Kemampuan Pemecahan Masalah Matematis Mahasiswa Calon Guru Matematika: Apa Dan Bagaimana Mengembangkannya. In Prosiding Seminar Nasional Matematika dan Pendidikan Matematika Jurusan Pendidikan Matematika FMIPA UNY (pp. 402-413). Yogyakarta: Universitas Negeri Yogyakarta.

Wulandari, \& Sinambela, N. (2017). Hubungan Kepercayaan Diri (Self-Confidence) dengan Kemampuan Pemecahan Masalah Matematika Siswa dengan Menggunakan Model Problem Based Learning di MAN Kisaran. Jurnal Inspiratif, 3(2), 102-108. 